(6) OPEN ACCESS

Uchiyama Orthopedic Clinic, Kashiwazaki-shi Niigata-ken Japan

\section{Correspondence to}

Dr Toru Uchiyama,

toru.uchiyama@nifty.com

Accepted 8 March 2019

\title{
Band acro-osteolysis in a middle-aged woman
}

\author{
Toru Uchiyama ${ }^{\oplus}$
}

\section{DESCRIPTION}

A female market worker in her 50 s presented with fingertip pain and swelling over the past 6 months, rendering it difficult to handle goods (figure 1). She had no symptoms of Raynaud's phenomenon or history of psoriasis, traumatic hand injury, frostbite or exposure to polyvinyl chloride. She had no family history of congenital bone dysplasia and psoriasis. Physical examination revealed mild clubbing of both thumbs and index fingers without nail deformities. Arterial oxygen saturation measured by pulse oximetry of the right index finger was $97 \%$. Radiography (figure 2) and MRI (figure 3) revealed band acro-osteolysis of the distal phalanges of both thumbs and index fingers. A destructive change was evident in the distal interphalangeal (DIP) joint of the right middle finger. There were no elevations in the levels of $\mathrm{C}$ reactive protein, serum alkaline phosphatase, calcium or intact parathyroid hormone. The serum was negative for rheumatoid factor, anti-DNA antibodies, anti-Scl-70 antibody and anticentromere antibodies.

The aetiologies of acro-osteolysis can be classified as idiopathic disease, occupational disease (caused by exposure to polyvinyl chloride, frostbite, or trauma), immunological disease (systemic sclerosis and psoriasis), infections (leprosy), endocrinological disease (hyperparathyroidism and diabetes mellitus), genetic condition (HajduCheney syndrome with or without syringomyelia) and lysosomal storage disorder (Gaucher's disease)..$^{12}$

The familial form of acro-osteolysis is often well established by the late teens, whereas the idiopathic form may not present until the third decade of life or later. ${ }^{2}$ Together with the age and other clinical findings described above, the aetiology of this case is likely suggestive of idiopathic form but is not conclusive.

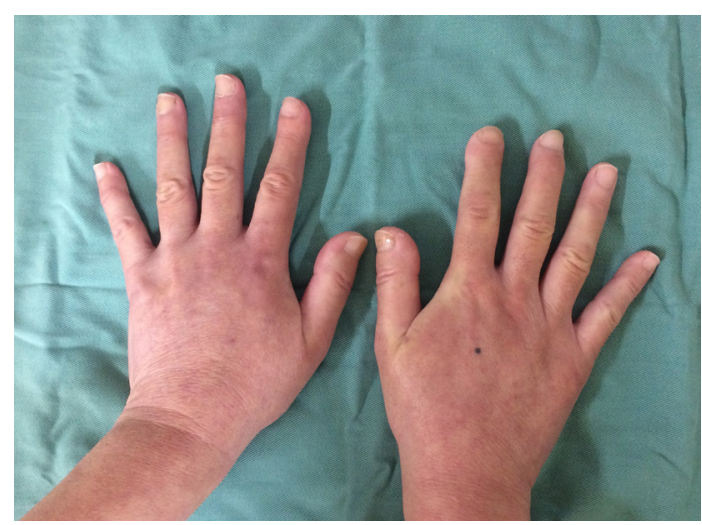

Figure 1 Mild clubbing was evident in both thumbs and index fingers.

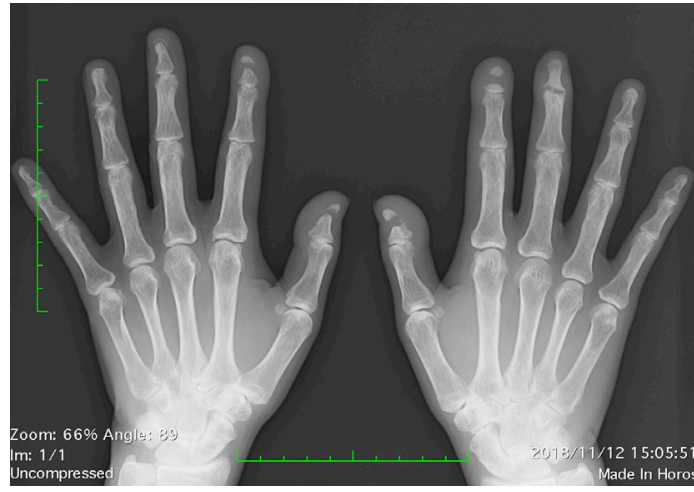

Figure 2 Radiograph of the hands revealing band acroosteolysis in the distal phalanges of both thumbs and index fingers.

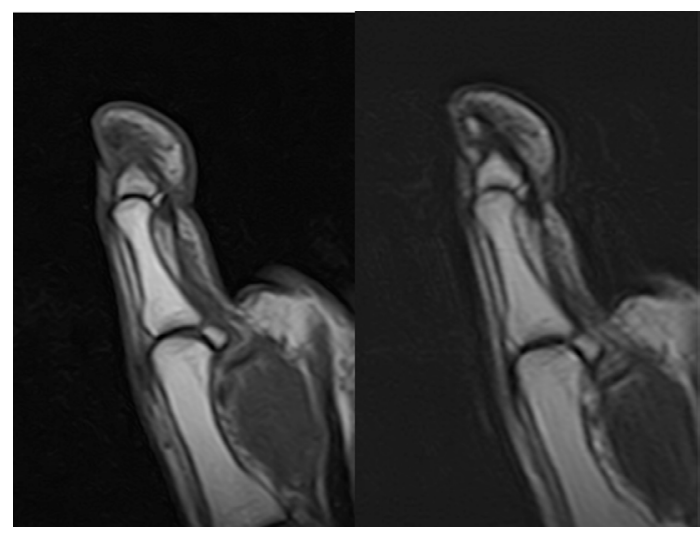

Figure 3 T1-weighted (left) and T2-weighted (right) magnetic resonance images of the distal phalanx of the right thumb.

\section{Learning points}

- There are two types of acro-osteolysis. One is osteolysis of the terminal tuft and the other (exemplified by the present case) is band/ transverse osteolysis of the shaft of the distal phalanx.

- Band acro-osteolysis may occur in exposure to polyvinyl chloride, renal osteodystrophy/ hyperparathyroidism, idiopathic non-familial acro-osteolysis, and Hajdu-Cheney syndrome or familial acro-osteolysis.

Acro-osteolysis is often a prominent feature of psoriatic arthritis. ${ }^{2}$ A destructive change of DIP joint of the right middle finger makes psoriatic arthritis a likely diagnosis. However, the patient does not meet the CASPAR criteria ${ }^{3}$ enough to diagnose psoriatic arthritis since there is no 
personal or family history of psoriasis, no typical psoriatic nail change and no current or past dactylitis. On the other hand, acro-osteolysis can also develop in patients with psoriasis without arthritis. ${ }^{12}$ Long-term follow-up is required to make the definitive diagnosis.

Acknowledgements The author thanks T Ozawa, H Kawashima, N Endo and S Kobayashi for the scientific discussions.

Contributors I am the sole author of this document.

Funding The authors have not declared a specific grant for this research from any funding agency in the public, commercial or not-for-profit sectors.

Competing interests None declared.

Patient consent for publication Obtained.
Provenance and peer review Not commissioned; externally peer reviewed.

Open access This is an open access article distributed in accordance with the Creative Commons Attribution Non Commercial (CC BY-NC 4.0) license, which permits others to distribute, remix, adapt, build upon this work non-commercially, and license their derivative works on different terms, provided the original work is properly cited and the use is non-commercial. See: http://creativecommons.org/ licenses/by-nc/4.0/

\section{REFERENCES}

1 Botou A, Bangeas A, Alexiou I, et al. Acro-osteolysis. Clin Rheumatol 2017;36:9-14.

2 Kemp SS, Dalinka MK, Schumacher HR. Acro-osteolysis. Etiologic and radiological considerations. JAMA 1986;255:2058-61.

3 Taylor W, Gladman D, Helliwell $P$, et al. Classification criteria for psoriatic arthritis: development of new criteria from a large international study. Arthritis Rheum 2006;54:2665-73

Copyright 2019 BMJ Publishing Group. All rights reserved. For permission to reuse any of this content visit https://www.bmj.com/company/products-services/rights-and-licensing/permissions/

BMJ Case Report Fellows may re-use this article for personal use and teaching without any further permission

Become a Fellow of BMJ Case Reports today and you can:

- Submit as many cases as you like

- Enjoy fast sympathetic peer review and rapid publication of accepted articles

- Access all the published articles

Re-use any of the published material for personal use and teaching without further permission

For information on Institutional Fellowships contact consortiasales@bmjgroup.com

Visit casereports.bmj.com for more articles like this and to become a Fellow 